\title{
A Comparison Of Students In Physical Education and Sports College and The Students In Other Departments In Terms Of Problem Solving Skills
}

\author{
Alpaslan Görücü ${ }^{1}$, Erkan Cantav $^{2}$ \\ ${ }^{1}$ Selcuk University, Faculty of Sport Sciences, Konya, Turkey \\ ${ }^{2}$ The Provincial Directorate of Youth Services and Sports, Ankara, Turkey \\ Correspondence: Alpaslan Görücü, Selcuk University, Faculty of Sport Sciences, Konya, Turkey.
}

Received: February 27, 2017

Accepted: March 17, 2017 Online Published: March 28, 2017

doi: $10.11114 /$ jets.v5i5.2310

URL: https://doi.org/10.11114/jets.v5i5.2310

\begin{abstract}
In this research, it is aimed to analyze the problem solving skills of university students in terms of different variables and to analyze the differences among the levels of perceived problem solving skill of the students of Physical Education and Sports College and other branch students. The sample consists of the university students from the School of Physical Education and Sports (128) and from the Department of Tourism and Hotel Management (104) from the Faculty of Economics and Administrative Sciences Department (162), summing up 394 students $\left(\mathrm{n}_{\text {female }}=193, \mathrm{n}_{\text {male }}=201\right.$ ) in total, based on the simple random sampling method. "Personal Information Form" and "Problem Solving Inventory (PSI)" were used as data collection tools. The T-test and One-Way ANOVA were used for normal distribution and LSD Test was used for determining the differences across groups. When the data were analyzed in terms of the variables of the study, it was found that a significant difference between the gender variable and problem solving skill in favour of males although there was no statistically significant difference between the problem solving skills and the place of birth of the students and the number of family members. It was found a significant difference between the students from School of Physical Education Sports and Department, students from Tourism and Hotel Management Department and students from the Faculty of Economics and Administrative Sciences Department in favour of the students from The Faculty of Economics and Administrative Sciences Department. Based on the findings of the research; Problem-solving skills of the students of the Physical Education and Sports College were found to be lower than the other departments.
\end{abstract}

Keywords: problem solving skills, physical education, university students

\section{Introduction}

Today, the individuals face more problems because of the increasingly complex social structure, developments in technology, economic-political-social crises. The perception of the concept of problem is mostly related with the questions involving mathematical operations. However, every situation disturbing the individuals in daily life can be regarded as a problem.

These problems can be simple problems to deal with, as well as severe and complex problems preventing individuals from living a healthy life. The problem arises when there are obstacles that prevent someone from reaching his/her goal. The features such as being a difficult for the person when facing with the problem, the need for the individual to solve it, and the cases in which the person has never encountered with this problem and the situation that there is no preparation for the solution, constitute the fundemental characteristics of a problem. The reactions given to these problems vary from person to person. The same problem is solved by many people in different ways. Some are successful in solving problems and others fail (Cüceloğlu, 2004). Individuals encounter with the problems described as "situations in which the person can not get through when confronted" (Demirel, 1994) or "every situation disturbing the individual physically and mentally in which they possibly have multiple solutions for them, the obstacles that are wanted to be overcame" (Karasar, 2000) in many times and seek out solutions for them.

It is not possible for the individual to have no problems throughout his or her lifetime, or to have a time in which every moment is unproblematic. It is not possible to find a place or life without problems. Trying to find suitable solutions to overcome these problems is natural and this continues throughout the lifetime. In this respective, life can be regarded as a problem solving process (Taylan, 1990). 
Problem-solving skills are the level of the skill to get the rules that can be used to prepare a solution by combining them properly in a way that can be used for solution (Bilen, 1999). Problem-solving skills are to understand and limit the problematic case, choose the appropriate method for solution, to develop the skills for using this method and analyzing the results when confronted with the problem (Ocak \& Eğmir, 2014). Problem solving skills are scientific processes that take place for an aim. They can be regarded as choosing the materials and behaviors that are effective to achieve and providing the appropriate ones that can be used (Demirel, 1994).

Problem-solving skill what is inherited by genes develops later with the contribution of education and experience. Problem solving requires time, effort, power and research. It is integrative because it is related with values, needs, goals, beliefs, skills, habits and behaviors and at the same time integrates factors such as creative thinking, intelligence, emotion, will and action. The problem-solving skill of the individual develops and brings the person to maturity (Taylan, 1990).

Problem-solving skills help individual to adjust himself/herself to the environment in which both individual and the group with him/her. For this reason, people need to learn to solve problems so that they can adapt to the environment they live in. Some problems have definite solutions or correct answers, but some have no precise solutions. The solution of such problems necessitates interdisciplinary knowledge, integrative thinking and creativity (Senemoğlu, 2004).

One of the most basic skills which should be gained by students in the renewed programs in other fields/departments as well as in physical education and sports colleges in our country is "problem solving skills". Problem solving is taught since childhood, and problem solving skills are being developed during school years (Miller \& Nunn, 2001; Çam \& Tümkaya, 2006; Serin, Serin \& Saygil1, 2010). Training programs of the universities are effective in bringing these skills to students. Therefore, it is important to determine the level of problem solving skills of university students in different departments / areas.

In addition, the fact that the active participation of the students in physical education and sports colleges in sportive activities is higher than the university students in other departments/fields, is important in terms that the role of sport in problem solving skill can be partially revealed. It is mentioned that there are many variables affecting the sportive performance efficiency. It can be said that one of these factors is the problem solving skill. The mental state and performance of the athletes are closely related to their level of problem solving skills. The situation that an athlete exercises too much or has a very high condition, is not enough for him/her to be successful. The athlete, who can get the right decisions as soon as possible, can gain an advantage to reach success more quickly.

Therefore, the athlete's problem-solving skills can be considered as an important factor in achieving success. If the effects of sportive activities on personality are also generalized; it can be said that they enable them to make them to speed up the socialization process by improving athlete-coach relationships, to channell aggression in a natural way or in accordance with social rules, to develop courage with extreme sports, as well as leadership skills and self-confidence, communication skills, fighting spirit, cooperation skills with team sports, self-discipline (Başer, 1986).

It is revealed that the individuals who see themselves as self-sufficient in problem solving skills, have higher self-esteem than the ones who do not see themselves as self-sufficient and use more appropriate methods in academic terms in a variety of studies in which problem-solving skills were investigated (Akbağ, 2000; Güven \& Akyüz, 2001; Korkut, 2002; Şahin \& Özbay, 2003; Katkat, 2003; Bozkurt, Serin \& Erman, 2004; Corner, 2004; Saracaloğlu, Serin \& Bozkurt, 2005; Öztürk, Sayar, Uhurad \& Tüzün, 2005; Çilingir, 2006; İnce \& Şen, 2006; Germi \& Sunay, 2006; Genç \& Kalafat, 2007; Türkçapar, 2009; Küçükkaragöz, Deniş, Ersoy \& Karataş, 2009; Kuru \& Karabulut, 2009; Bezci, 2010; Uslu \& Girgin, 2010; Yavuz, Arslan \& Gülten, 2010; Aylar \& Aksin, 2011; Yenice, 2011; Pulur, Karabulut \& Koç, 2012; Kolayiş, Turan \& Ulusoy, 2012; Kuloğlu \& Arı, 2014).

Those who know how to use problem-solving skills effectively from the moment they start work, and those who do know what to do in case of ambiguous situations, can easily and effectively solve the problems (whether the source of the problems are resulted from their actions or not) they encounter in their professional and civil life. University students should display a fortitude to obstacles in their life after graduation and should use problem-solving skills appropriately in order to be successful in their professional lives.

It is of having importance to examine the problem-solving skills of physical education and sport college students and other university students due to their role as a good model in the future, to have a qualified job and the role of improving creativity and social skills, based on the information provided above.

In this context, the aim of the study is to analyze the problem-solving skills of university students in terms of various variables and to analyze the difference between the levels of perceived levels of problem-solving skills of the students of the Physical Education School and the other branch students. 


\section{Material and Method}

The study was a descriptive study and it was conducted to a total of 394 students (193 of them are female and 201 of them are male), who were studying at Gazi University in the academic year of 2015-2016.

\subsection{Sample}

Target sample of the study consist of the students in Gazi University and the sample consists of 128 volunteer students from the Faculty of Physical Education and Sports, 162 students from the Faculty of Economics and Administrative Sciences and 104 volunteer students from the Tourism and Hotel Management Department determined by simple random sampling method.

\subsection{Data Collection Tools}

"Personal Information Form" and "Problem Solving Inventory" were used as data collection tool.

\subsubsection{Personal Information Form}

In the first part of the questionnaire includes variables (regarding gender, place of birth and number of family members) for the personal information of the students participating in the survey.

\subsubsection{Problem Solving Inventory (PSI)}

It was developed by Heppner \& Petersen (1982) to determine how individuals perceive themselves in terms of their competency to solve problems by taking the problem-solving steps such as "general orientation", "definition of problem", "alternative generation", "decision making" and "evaluation" into consideration. It is adapted into Turkish by Taylan (1990) with Savaşır \& Şahin (1997). The scale is a Likert type 6-point scale consisting of 14 negative items with a total of 35 items.

The number 1 is assigned to the response "always act like this", the number 2 is assigned for the response as "mostly act like this", the number 3 is assigned for the response as "often act like this", the number 4 is assigned for the response as "occasionally act like this", the number 5 is assigned to the response as "seldomly act like this", the number 6 is assigned to the response as "never act like this". 14 items are reversely scored quesitons in the scale while the total number of other questions is 21. The lowest score for the entire scale is 32, the highest score is 192 (Taylan, 1990; Keleş, 2000). The high values of the total scores obtained from the whole scale indicates that the individual perceives himself as inadequate in problem solving skills. In the statistical evaluations of the data obtained from the scale in the study, the total score of PSI was used and no studies were done about the subgroups of the scale.

The Cronbach Alpha internal consistency coefficient of the adapted version of the scale was found to be .88 and it is found between .59 and .78 for the subdimensions (Savaşır \& Şahin, 1997). The Cronbach alpha values found in different studies on the reliability of the scale are between 0.73 and 0.94 (Taylan, 1990; Keleş, 2000). In this study, the Cronbach alpha value for the PSI was calculated as 0.87 from the results obtained by the scale.

The necessary concents were taken from the institutions concerned with the research. Before the application, explanations were made by the researchers about the purpose of researches and how to fill in the questionnaires, and the study is based on the voluntary the participation of the students.

\subsection{Analysis of Data}

The data was analyzed with SPSS 21.0 computer package program, and the arithmetic mean and standard deviation of all parameters were calculated. The "Single Sample Kolmogorov-Smirnov" test was performed to determine the homogeneity of tests fot the data and it was determined that the data showed a normal distribution. One-way analysis of variance (ANOVA) test was used to compare the problem-solving skills of the groups, the place of birth of the sample group and the monthly income of the families, and the LSD (Least Significant Difference) test was used to determine the source of the significant difference. The problem-solving abilities of the sample group were compared with the "independent $\mathrm{t}$ " test. $\mathrm{P}<0.05$ level were accepted as significant for the research.

\section{Results}

\subsection{Descriptive Statistics}

In Table 1, statistical analyzes of the students participating in the research were given in terms of department and gender. 
Table 1. Distribution of students in terms of their department and gender

\begin{tabular}{lllll}
\hline \multirow{2}{*}{ Departments } & & \multicolumn{2}{c}{ Gender } & \multirow{2}{*}{ Total } \\
\cline { 3 - 4 } Physical Education and Sports College & $\mathrm{N}$ & 67 & 61 & 128 \\
& $\%$ & 52,3 & 47,7 & 100 \\
\hline \multirow{2}{*}{ Faculty of Economics and Administrative Sciences } & $\mathrm{N}$ & 85 & 77 & 162 \\
& $\%$ & 52,5 & 47,5 & 100 \\
\hline \multirow{2}{*}{ Tourism and Hotel Management Department } & $\mathrm{N}$ & 49 & 55 & 104 \\
& $\%$ & 47,1 & 52,9 & 100 \\
\hline \multirow{2}{*}{ Total } & $\mathrm{N}$ & 201 & 193 & 394 \\
& $\%$ & 51 & 49 & 100 \\
\hline
\end{tabular}

In Table 1, 52.3\% of the students in the Physical Education and Sports College who participated in the survey are male and $47.7 \%$ are female. $52.5 \%$ of the students of the Faculty of Economics and Administrative Sciences are male and 47.5\% are females. $47.1 \%$ of the students in the Tourism and Hotel Management Department are male and 52.9\% are female. $51 \%$ of the participants were male and $49 \%$ were female overall.

Table 2. Distribution of students in terms of their place of birth

\begin{tabular}{lllllll}
\hline \multirow{2}{*}{ Departments } & \multicolumn{2}{c}{ Place of Birth } & & \\
\cline { 3 - 6 } & & Village & Town & District & Province & Total \\
\hline \multirow{2}{*}{ Physical Education and Sports College } & $\mathrm{N}$ & 25 & 22 & 36 & 45 & 128 \\
& $\%$ & 19,5 & 17,5 & 28,1 & 35,2 & 100 \\
\hline \multirow{2}{*}{ Faculty of Economics and Administrative Sciences } & $\mathrm{N}$ & 43 & 47 & 31 & 41 & 162 \\
& $\%$ & 26,5 & 29,0 & 19,1 & 25,3 & 100 \\
\hline \multirow{2}{*}{ Tourism and Hotel Management Department } & $\mathrm{N}$ & 21 & 20 & 29 & 34 & 104 \\
& $\%$ & 20,2 & 19,2 & 27,9 & 32,7 & 100 \\
\hline \multirow{2}{*}{ Total } & $\mathrm{N}$ & 89 & 89 & 96 & 120 & 394 \\
& $\%$ & 22,6 & 22,6 & 24,4 & 30,5 & 100 \\
\hline
\end{tabular}

In Table 2, 19.5\% of the students participated in the survey in the Physical Education and Sports College, are from villages, $17.2 \%$ of them are from towns, $28.1 \%$ of them are from the districts and $35.2 \%$ of them were born in province (metropolitan cities). 26.5\% of the students participated in the survey in the Faculty of Economics and Administrative Sciences, are from villages, $29 \%$ of them are from towns, $19.1 \%$ of them are from the districts and $25.3 \%$ of them were born in province / metropolitan cities. $20.2 \%$ of the students participated in the survey in the Tourism and Hotel Management Department, are from villages, $19.2 \%$ of them are from towns, $27.9 \%$ of them are from the districts and $32.7 \%$ of them were born in province / metropolitan cities. In general respect, $22.6 \%$ of the students participated in the survey are from villages, $22.6 \%$ of them are from towns, $24.4 \%$ of them are from the districts and $30.5 \%$ of them were born in province (metropolitan cities).

In Table 3, 31,2\%, of the Physical Education and Sports College students participated in the research have 1-3 individuals in their family, 53,9\% of them have 4-5 individuals, $10,2 \%$ of them have $6-7$ individuals, $4,7 \%$ of them have 8 and above individuals in their family. $37 \%$ of the Faculty of Economics and Administrative Sciences students participated in the research have 1-3 individuals in their family, $43,8 \%$ of them have $4-5$ individuals, $11,1 \%$ of them have 6-7 individuals, $8 \%$ of them have 8 and above individuals in their family. $35.6 \%$, of the Faculty of the Tourism and Hotel Management students participated in the research have 1-3 individuals in their family, 51\% of them have 4-5 individuals, $9,6 \%$ of them have $6-7$ individuals, $3,8 \%$ of them have 8 and above individuals in their family. In general, $34.8 \%$, of the students participated in the research have 1-3 individuals in their family, $49 \%$ of them have $4-5$ individuals, $10,4 \%$ of them have 6-7 individuals, 5,8\% of them have 8 and above individuals in their family.

Table 3. Distribution of of the students according to the number individuals in their family

\begin{tabular}{|c|c|c|c|c|c|c|}
\hline \multirow{2}{*}{ Departments } & & \multicolumn{4}{|c|}{ Number of Family Members } & \multirow{2}{*}{ Total } \\
\hline & & $1-3$ & $4-5$ & $6-7$ & 8 and above & \\
\hline \multirow{2}{*}{ Physical Education and Sports College } & $\mathrm{N}$ & 40 & 69 & 13 & 6 & 128 \\
\hline & $\%$ & 31,2 & 53,9 & 10,2 & 4,7 & 100 \\
\hline \multirow{2}{*}{ Faculty of Economics and Administrative Sciences } & $\mathrm{N}$ & 60 & 71 & 18 & 13 & 162 \\
\hline & $\%$ & 37,0 & 43,8 & 11,1 & 8,0 & 100 \\
\hline \multirow{2}{*}{ Tourism and Hotel Management Department } & $\mathrm{N}$ & 37 & 53 & 10 & 4 & 104 \\
\hline & $\%$ & 35,6 & 51,0 & 9,6 & 3,8 & 100 \\
\hline \multirow{2}{*}{ Total } & $\mathrm{N}$ & 137 & 193 & 41 & 23 & 394 \\
\hline & $\%$ & 34,8 & 49,0 & 10,4 & 5,8 & 100 \\
\hline
\end{tabular}


Table 4. Relationship between gender of students and problem solving skills

\begin{tabular}{llllll}
\hline Gender & $\mathrm{N}$ & $\mathbf{X}$ & $\mathrm{S}$ & $\mathrm{t}$ & $\mathrm{p}$ \\
\hline Male & 201 & 107,33 & 16,66 & $-3,693$ & $0,034^{*}$ \\
Female & 193 & 111,03 & 17,82 & & \\
\hline $\mathrm{p}<.05$ & & & & &
\end{tabular}

In Table 4, the $t$ test was used to determine whether the students' total problem solving averages are significantly different according to the gender variable. It was found that there was a significant difference between problem solving scores and gender variables $(t=-3.693, p<.05)$. When the average of the total points was examined, it was determined that the average of problem solving total scores of male students was lower than the average of total score of female students' problem solving skills and that problem solving skills were determined to be significant in favour of male students.

Table 5. The relationship between students' birth places and problem solving abilities

\begin{tabular}{llllll}
\hline \multicolumn{1}{c}{ Place of Birth } & $\mathrm{N}$ & $\overline{\mathbf{X}}$ & $\mathrm{SS}$ & $\mathrm{F}$ & $\mathrm{p}$ \\
\hline Village & 89 & 107,10 & 18,22 & & \\
Town & 89 & 107,16 & 15,03 & 0,875 & 0,341 \\
District & 96 & 108,86 & 17,97 & & \\
Province & 120 & 112,34 & 17,41 & & \\
\hline
\end{tabular}

In Table 5, one-way ANOVA was used to examine whether the average of problem solving total scores of the students who participated in the research are significantly different according to the place of birth variable. It was found that here was no statistically significant difference between problem solving abilities of students participating in the study $(\mathrm{p}>0,05)$.

Table 6. The relationship between the number of family members of the students and their problem solving abilities

\begin{tabular}{llllll}
\hline \multicolumn{1}{c}{ Number of Individuals } & $\mathrm{N}$ & $\mathbf{X}$ & $\mathrm{SS}$ & $\mathrm{F}$ & $\mathrm{p}$ \\
\hline $1-3$ & 137 & 108,31 & 16,16 & & \\
$4-5$ & 193 & 110,03 & 17,83 & 1,380 & 0,248 \\
$6-7$ & 41 & 111,12 & 18,78 & & \\
8 and above & 23 & 109,14 & 17,31 & & \\
\hline
\end{tabular}

In Table 6, one-way ANOVA was used to examine whether the average of problem solving total scores of the students who participated in the research are significantly different according to the number of family members. It was found that there was no statistically significant difference between the problem solving skills of the students who participated in the research according to the number of family members $(p>0,05)$.

Table 7. The comparison of the total scores of the problem-solving skills among the departments

\begin{tabular}{|c|c|c|c|c|c|c|c|}
\hline & Departments & $\mathrm{N}$ & $\overline{\mathbf{X}}$ & SS & $\mathrm{F}$ & $\mathrm{p}$ & LSD \\
\hline 1 & Physical Education and Sports College & 128 & 114,32 & 19,34 & \multirow{3}{*}{15,922} & \multirow{3}{*}{$0,000^{*}$} & \multirow{3}{*}{$\begin{array}{l}1-2 \\
2-3\end{array}$} \\
\hline 2 & Faculty of Economics and Administrative Sciences & 162 & 103,62 & 14,24 & & & \\
\hline 3 & Tourism and Hotel Management Department & 104 & 111,36 & 16,72 & & & \\
\hline
\end{tabular}

In Table 7, one-way ANOVA was used to investigate whether the average of problem solving total scores of the students who participated in the research are significantly different according to their departments. It was found that there was statistically significant difference between the problem solving abilities of the students who participated in the research $(\mathrm{p}<0,05)$.

LSD test was used to determine which group have the significant difference. According to the findings of the research, the total score averages of the problem solving skills of the students of the Faculty of Economics and Administrative Sciences are significantly lower than the average of the total scores of the students in Vocational School of Tourism and Hotel Management and there is a significant difference in favor of the students of the Faculty of Economics and Administrative Sciences $(\mathrm{p}<0,05)$. The total point average of problem solving skills of the students of the Faculty of Economics and Administrative Sciences is also significantly lower than the average of the total scores of the students of Physical Education and Sports College and there is a significant difference in favor of the students of the Faculty of Economics and Administrative Sciences $(\mathrm{p}<0,05)$.

\section{Conclusion and Discussion}

According to the results obtained from the researches conducted by the students in Gazi University School of Physical Education and Sports, Faculty of Economics and Administrative Sciences and Tourism and Hotel Management Department to determine the problem solving levels of them, the problem solving abilities of male and female students were found to to have significant differences in favor of male students. In other words, male students perceive 
themselves more positively compared to female students in terms of problem solving skills. This shows that male students are more rational, insistent, positive and competent with the problems they have encountered. Problem solving involves a series of efforts to get rid of difficulties in order to achieve an aim.

There are studies in the literature showing similarities and differences with the findings obtained from this research. Similarly, Akbağ (2000) found that, in his study conducted to university students, males tend to be more problem-oriented than females in terms of problem-focused coping styles. On the other hand, it was found that found that male students' problem-solving skills were higher than their female counterparts in the studies of Çelikkaleli \& Gündüz (2010) and Korkut (2002)'s researches about the adolescents, Bezci (2010)'s research regarding on taekwondo coaches, Genç \& Kalafat (2007)'s research on teacher candidates Türkçapar (2009) with Kuru \& Karabulut (2009)' researches regarding students in School of Physical Education and Sports department. Similarly, it was also found that found that male students' problem-solving skills were higher than their female counterparts in the studies of İnel, Evrekli \& Türkmen (2011)'s research on the teacher candidates in Primary School Teaching Department, Aylar \& Aksin (2011)'s research on the teacher candidates in Social Sciences Teaching Department, Yavuz, Arslan \& Gülten (2010)'s research regarding in the teacher candidates in Primary School Teaching Department and Social Sciences Teaching Department.

In addition, Pulur, Karabulut \& Koç (2012) found that the problem solving skills of males in swimming and track and field branches were higher than those of female athletes in their study of problem-solving skills of senior collegiate athletes in different disciplines. This indicates that male athletes have a higher problem solving skill than girls in problem solving. In addition, researchers also point out that male sportsmans engaged in swimming and athletics have higher problem solving skills than other sportsmans when their scores are generally evaluated.

Another reason for the fact that female students who attend university tend to have a negative tendency of approaching toward problems may be due to the reason that female university students more focus on the unreasonable thoughts than male university students (Bilge \& Arslan, 2001). On the other hand, Tamres, Janicki \& Helgeson (2002) found that girls had higher problem-solving skills than boys. Similarly, it was found that the problem-solving skills of women are higher than men in the researches of Katkat (2003) and Arlı, Altunay \& Yalçınkaya (2011) on the teacher candidates, the research of İnce \& Şen (2006) with basketball players, the research of Keskin \& Yıldırım (2008) by university students, the research of Şara (2012) with primary school teachers. Küçükkaragöz, Deniş, Ersoy \& Karataş (2009) found that male teacher candidates' problem solving skills were higher than female teacher candidates, although there was no significant difference between them. Kuloğlu \& Arı (2014) found that there was no a significant difference between male and female teacher candidates in terms of their problem-solving abilities, but problem-solving skills of males were higher than females. The contradiction of this research result with the research results mentioned before may be due to differences in sample groups.

There was no significant difference between problem-solving abilities of students with their birth place whether it was a village, a town or a district. The reason why there was no significant difference between the place of birth variable and problem solving skills might be due to changes in our social structure. For a long time the social structure in our country has undergone great changes. It is known that large migrations took place in cities from rural regions as a natural consequence of industrialization. As a result of these migrations, even though the place of birth is village-town-district, most of the students spend their lives in large cities. It can be seen that there is a similarity among the students in terms of their social life. This may have brought about homogeneity in terms of problem-solving skills between a student born in a village and a student born in a big city. In addition, it seems that the fact that transportation and mass media can reach the farthest regions might have contributed to this situation. Today, means of transport have developed and communication has become widespread. It is now easily accessible from the most remote villages. Those living in rural areas can benefit from mass media. In this sense, there is no difference between a person whose birthplace is in rural areas and a person whose birthplase is in urban areas in terms of reaching and acquiring information. At the same time, the differences about encountering with stimulants disappeared. Thus, regardless of the place of birth, it can be said that today's students are similar to each other in terms of problem-solving skills.

In the literature, it was also seen that there were researches which didn't support the result of this research. In the study conducted by Başar (2011) on nurses and nursing students, problem-solving abilities of students who spent most of their childhood in districts were higher than problem-solving abilities of students who spend most of their childhood in cities.

Similarly, Topal (2011) research has shown that the majority of students who spend their lives in big cities are more persistent and tenacious than those who live in the village. It is predicted that the reason why the results of the mentioned studies differ from the results of our research is due to the differences in sample groups. It is observed that there is no relationship between students' birth places and problem solving abilities in the context of accessible resources. This supports the findings of our research to a large extent, with the exception of the results of Başar (2011). 
It was found that there was no significant difference between the number of family members whether they are 1-3, 4-5, 6-7 and 8 and the problem-solving abilities of the students. It was found that researches supporting the findings of our research in the literature. There was no significant difference between the number of family members the problem-solving abilities of the students in the research conducted by Başar (2011) and by Elkin \& Karadağl1 (2015) with university students and by Çağlayan, Taşgın \& Yıldız (2008) with sports high school students.

Some of the research findings related to the subject are different from our findings. In Çilingir (2006)'s research, it is concluded that there is a significant relationship between the number of siblings and problem-solving skills. Similarly, Dalkıliç (2006) found a significant relationship between the number of siblings and problem-solving skills in his research on adolescents. It is seen that the two researches carried out at the high school level. It is known that adolescent students and university students show different developmental characteristics and exhibit different approaches to events and events. Moreover, according to Taylan (1990), the factors affecting the solution of the problem are the development and maturity level. In this sense, the contrast between these two research findings and our research findings may be due to age differences in the sample groups.

There is a significant difference between the problem-solving skills of the students in the School of Economics and Administrative Sciences, the Department of Tourism and Hotel Management and the School of Physical Education and Sports. In terms of problem solving skills, the Faculty of Economics and Administrative Sciences students perceive themselves more positively than the students of Tourism and Hotel Management and the School of Physical Education and Sports. Physical Education and Sports College students are at the last place in terms of problem solving skills.

Some related research results are different from the results of our research. It was found that there was a significant relationship among the studies of Çam \& Tümkaya (2006), Elkin \& Karadağlı (2015) with university students, the study of Çevik \& Özmaden (2013) with music and physical education teacher candidates, the research of Kırılmazkaya (2010) with elementary science and class teacher candidates, the research of Aylar \& Aksin 2011) with teacher candidates in social studies, the research of Bayrak, İnan \& Kartal (2015) with teacher candidates for physical education and elementary schools. It can be argued that the difference between the results of this study with the studies in the literature are caused by the differences in the sample groups.

According to the results of the research, the students of the Faculty of Economics and Administrative Sciences perceive themselves more positively than the students of the Department of Tourism and Hotel Management and the School of Physical Education and Sports in terms of problem solving skills. Despite being in the same university, the differentiation of pupils in different faculties in terms of problem-solving skills may be due to the instructional program implemented in schools. Differences in faculties 'compulsory and elective courses may also be reflected in students' problem-solving skills. Lectures of the Faculty of Economics and Administrative Sciences may be more instructive in terms of problem-solving skills than other faculty courses. According to Senemoğlu (2004), the solution of problems requires interdisciplinary knowledge, multi-faceted thinking and creativity. In this sense, the Faculty of Economics and Administrative Sciences may have improved the characteristics of the students with its instructional program. Many researches show that problem-solving skills can be learned and educated (Korkut, 2002; Altunçekiç, Yaman \& Koray, 2005; Türnüklü \& Yeşildere, 2005; Genç \& Kalafat, 2007; Yıldırım \& Yalçın, 2008). The fact that the physical education students are at a lower level of problem solving skills than the other faculty students may also be due to the content of the program. The fact that there are lessons that require more physical participation than the other faculties may have created this disparity in the way that students tend to concentrate on sporting activities during school hours.

As a result, in this study; male students in the sample group were found to perceive themselves better than female students in terms of problem solving skills. There is no significant relationship between the birthplace and the number of individuals in family of the students with their problem solving skills. Students in the Faculty of Economics and Administrative Sciences students, Tourism and Hotel Management are more effective than Physical Education and Sports College students in terms of problem solving skills.

In parallel with these results, the recommedations can be given below for further researches;

Scientific studies revealed that the sport contributes to both physical and psychological health of people. At the same time, regular sports life is expected to have a positive effect on the individual's problem-solving skills. For this reason, the curriculum of the School of Physical Education and Sports should be designed to improve students' problem solving skills.

Further subsequent researches on both field, vocational and general cultural courses should be undertaken and diverse strategies and methods should be used to enhance students' learning. In this way, students can improve problem solving capacities.

It should be tried to find solutions why the students perceive themselves as inadequate in terms of problem solving skill 
by finding out the groups with low or high level of problem solving skill among the students of Physical Education and Sports School to find out by qualitative researches.

It is suggested that quantitative and qualitative researches should be done with the students of Physical Education and Sports College in order to determine the problem solving skills and the different factors affecting them.

The lack of longitudinal design of this research can be considered as a weakness of the study. For this reason, it is recommended to monitor the same student group longitudinally and to compare the results with schools with different educational models.

\section{References}

Akbağ, M. (2000). An investigation of the coping styles of the university students in terms of negative automatic thoughts, ego states ain transactional analysis and other variables. (Doctorate Thesis). Marmara University, Istanbul, Turkey.

Altunçekiç, A., Yaman, S., \& Koray, Ö. (2005). A research on teacher candidates' self-efficacy beliefs and problem-solving skills (Kastamonu province sample). Kastamonu Education Journal, 13(1), 93-102.

Arlı, D., Altunay, E., \& Yalçınkaya, M. (2011). The relationship of emotional intelligence, problem solving and academic success of pre-service teachers. Academic View Journal, 25, 1-23.

Aylar, F., \& Aksin, A. (2011). The research on self-efficiency belief level and problem solving skills of social studies pre-service teachers (Amasya sample). Ahi Evran University Journal of Education, 12(3), 299-313.

Başar, G. (2011). The assesment of problem solving and communication skills of nurses and nursing students. (Master's Thesis). Istanbul Science University, Istanbul, Turkey.

Başer, E. (1986). Applied Sports Psychology. Bağırgan Publisher, Ankara.

Bayrak, E., İnan, H., \& Kartal, M. (2015). Examining problem solving skills of prospective students who studying in school of physical education class and sports and school teaching class. The Journal of Social Science, 2(5), 308-317.

Bezci, Ş. (2010). An examination of the relationship between Taekwondo coaches' ability to cope with stress and problem solving skills. (Doctorate Thesis). Gazi University, Ankara, Turkey.

Bilen, M. (1999). Instruction From Planning To Production. Anı Publisher, Ankara.

Bilge, F., \& Arslan, A. (2001). Non-rational thought levels should assess problem skills of different university students. Turkish Psychological Counseling and Guidance, 2(13), 7-18.

Bozkurt, N., Serin, O., \& Erman, B. (2004). A comparative analysis of communication skills, problem solving and audit focus levels of elementary school primary level teachers. $7^{\text {th }}$ Educational Science Congress Book, 2, 2373-2393.

Çağlayan, H. S., Taşgın, Ö., \& Yıldız, Ö. (2008). Examination of problem solving skills of high school students in terms of various variables. Niğde University Journal of Physical Education and Sport Sciences, 2(1), 62-77.

Çam, S., \& Tümkaya, S. (2006). University students' interpersonal problem solving. The Journal of Cukurova University Social Sciences Institute, 15(2), 119-132.

Çelikkaleli, Ö., \& Gündüz, B. (2010). Problem solving and self-efficacy beliefs on adolescece. Journal of Social Sciences Institute, 19(2), 361-377.

Çevik, D. B., \& Özmaden, M. (2013). Problem solving skills of preservice teachers. Journal of Research in Education and Teaching, 2(3), 270-275.

Çilingir, A. (2006). The comparison between high school and high school of science students' social and problem solving skills. (Master's Thesis). Ataturk University, Erzurum, Turkey.

Corner, M. (2004). Task characteristics and performance in interpersonal cognitive problem solving. The Journal of Psychology, 138(2), 185-191. https://doi.org/10.3200/JRLP.138.2.185-192

Cüceloğlu, D. (2004). The Human and His Behaviour. Remzi Publisher, İstanbul.

Dalkılıç, M. (2006). Examination of perceived problem solving and communication skills of high school students in relation to parents and adolescents according to some variables. (Master's Thesis). Ege University, İzmir, Turkey.

Demirel, Ö. (1994). General Instruction Methods. Usem Publisher, Ankara.

Elkin, N., \& Karadağl1, F. (2015). Evaluation of university students problem solving skills. Adlyaman University Journal of Health Science, 1(1), 1-8. 
Genç, S. Z., \& Kalafat, T. (2007). The research on evaluation of prospective teachers' democratic attitudes and problem solving skills according as different variables. Pamukkale University Education Faculty Journal, 2(22), 10-22.

Germi, H., \& Sunay, H. (2006). Evaluation of problem-solving skills of sports managers working in youth and sports general directorate. $9^{\text {th }}$ International Sports Science Congress, Muğla.

Güven, A., \& Akyüz, M. Y. (2001). Teacher candidates' views on communication and problem solving skills. Ege Education Journal, 1(1), 13-22.

Heppner, P. P., \& Petersen, C. H. (1982). The development and implications of a personal problem solving inventory. Journal of Counseling Psychology, 29, 66-79. https://doi.org/10.1037/0022-0167.29.1.66

İnce, G., \& Şen, C. (2006). Determination of the problem-solving skills of players in basketball league in Adana. Spormetre Journal Of Physical Education and Sport Sciences, 4(1), 5-10.

İnel, D., Evrekli, E., \& Türkmen, L. (2011). Researching of pre-service elementary teachers’ problem solving skills. Pamukkale University Education Faculty Journal, 29(1), 167-178.

Karasar, N. (2000). Scientific Research Method. Nobel Publisher, Ankara.

Katkat, D. (2003). Comparison of problem solving skills of teacher candidates in terms of gender and field. Journal of Gazi Physical Education and Sport Sciences, 8(3), 11-18.

Keleş, O. B. (2000). Relationship between problem solving and locus of control of educational administrators. (Doctorate Thesis). Ankara University, Ankara, Turkey.

Keskin, G., \& Yıldırım, G. Ö. (2008). The evaluation of university students in terms of problem solving, autonomy, multiple intelligences based on constructive approach norms. Journal of Inonu University Education Faculty, 9(16), 67-88.

Kırllmazkaya, G. (2010). The comparison between science and class of candidate teachers social and problem solving skills. (Master's Thesis). Firat University, Elazığ, Turkey.

Kolayiş, H., Turan, H., \& Ulusoy, Y. O. (2012). Comparison of problem-solving disposition of students in physical education teacher and psychological counseling and guidance. Procedia Social and Behavioral Science, 46, 1939-1942. https://doi.org/10.1016/j.sbspro.2012.05.407

Korkut, F. (2002). Problem solving skills of high school students. Hacettepe University Journal of Education, 22, 177-184.

Küçükkaragöz, H., Deniş, H., Ersoy, E., \& Karataş, E. (2009). An investigation into primary level mathematics, science and Turkish teacher candidates' learning styles and problem solving skills. $1^{\text {th }}$ International Education Research Congress, Çanakkale.

Kuloğlu, A., \& Arı, Ü. (2014). Examination of science and technology teacher candidates' problem solving skills in terms of some variables. Kilis 7 Arallk University Social Sciences Journal, 4(8), 95-109.

Kuru, E., \& Karabulut, E. O. (2009). Analysis of problem solving skills of school of physical education and sports students taking or not taking rhythm training and dance lesson in terms of various variables. Gazi Education Faculty Journal, 29(2), 441-458.

Miller, M., \& Nunn, G. D. (2001). Using Group Discussions to Improve Social Problem-Solving and Learning. Education (Chula Vista, Calif), 121, 470-475.

Ocak, G., \& Eğmir, E. (2014). Investigation of pre service teachers' problem solving skills in terms of different variables. Asian Journal of Instruction, 2(1), 27-45.

Öztürk, M., Sayar, K., Uhurad, I., \& Tüzün, Ü. (2005). The prevalence of social phobia in mothers of social phobic children. Bulletin of Clinical Psychopharmacology, 15, 60-64.

Pulur, A., Karabulut, E. O., \& Koç, H. (2012). A review of the problem-solving skills of high level collegiate athletes from different branches. Spormetre Journal Of Physical Education and Sport Sciences, 5(1), 1-6.

Şahin, F., \& Özbay, Y. (2003). Examining the relationship between problem areas, problematic levels, problem solving skills and help seeking behaviors of university students. $7^{\text {th }}$ National Congress of Counseling and Guidance, Malatya.

Şara, P. (2012). A study on primary school candidate teachers' learning and study strategies, problem solving skills and locus of control in terms of various variables. (Doctorate Thesis). Dokuz Eylül University, Izmir, Turkey.

Saracaloğlu, A. S., Serin, O., \& Bozkurt, N. (2005). Examination of the level of problem solving and supervision of 
graduate students of educational science institute in terms of some variables. Journal of Buca Education Faculty, $17,237-245$.

Savaşır, İ., \& Şahin, N. H. (1997). Evaluation in Cognitive-Behavioral Therapies: Commonly Used Scales. Turkish Psychological Association Publications, Ankara.

Senemoğlu, N. (2004). Development, Learning and Teaching. Gazi Publisher, Ankara.

Serin, O., Serin, N. B., \& Sayg1l, G. (2010). Developing problem solving inventory for children at the level of primary education (PSIC). Primary Education Online, 9, 446-458, http://ilkogretim-online.org.tr

Tamres, L.K., Janicki, D., \& Helgeson, V. S. (2002). Sex differences in coping behavior: a meta-analytic review and an examination of relative coping. Personality and Social Psychology Review, 6(1), 2-30. https://doi.org/10.1207/S15327957PSPR0601_1

Taylan, S. (1990). Adaptation and validity and reliability studies of Heppner's problem-solving inventory. (Master's Thesis). Ankara University, Ankara, Turkey.

Topal, H. (2011). Analysis of the relationship of interpersonal problem solving skills and orientation in connection with dysfunctional attitudes in the faculty of education. (Master's Thesis). Cukurova University, Adana, Turkey.

Türkçapar, Ü. (2009). The problem-solving skills of physical education sports college students in terms of different variables. Journal of Kirşehir Education Faculty, 10(1), 129-139.

Türnüklü, E. B., \& Yeşildere, S. (2005). Problem, problem solving and critical thinking. Journal of Gazi Education Faculty, 25(3), 107-123.

Uslu, M., \& Girgin, Ç. (2010). The effects of residential conditions on the problem solving skills of university students. Procedia-Social and Behavioral Sciences, 2(2), 3031-3035. https://doi.org/10.1016/j.sbspro.2010.03.459

Yavuz, G., Arslan, Ç., \& Gülten, D. C. (2010). The perceived problem solving skills of primary mathematics and primary social sciences prospective teachers. Procedia Social and Behavioral Sciences, 2, 1630-1635. https://doi.org/10.1016/j.sbspro.2010.03.249

Yenice, N. (2011). Investigating pre-service science teachers' critical thinking dispositions and problem solving skills in terms of different variables. Educational Research and Reviews, 6(6), 497-508.

Yıldırım, H. İ., \& Yalçın, N. (2008). The effect of science education based on critical thinking skills on prospective science teachers' problem solving skills. Journal of Gazi Education Faculty, 28(3), 165-187.

\section{Copyrights}

Copyright for this article is retained by the author(s), with first publication rights granted to the journal.

This is an open-access article distributed under the terms and conditions of the Creative Commons Attribution license which permits unrestricted use, distribution, and reproduction in any medium, provided the original work is properly cited. 